\title{
Surgical Incision-Induced Nociception Causes Cognitive Impairment and Reduction in Synaptic NMDA Receptor 2B in Mice
}

\author{
Xiaoqin Zhang, ${ }^{1,2 *}$ Xin Xin, ${ }^{1,3 *}$ Yuanlin Dong, ${ }^{1}$ Yiying Zhang, ${ }^{1}$ Buwei Yu, ${ }^{2}$ Jianren Mao, ${ }^{4}$ and Zhongcong Xie ${ }^{1}$ \\ ${ }^{1}$ Geriatric Anesthesia Research Unit, Department of Anesthesia, Critical Care and Pain Medicine, Massachusetts General Hospital and Harvard Medical \\ School, Charlestown, Massachusetts, 02129-2060, ${ }^{2}$ Department of Anesthesia, Rui Jin Hospital, School of Medicine, Shanghai Jiao Tong University, \\ Shanghai 200025, P.R. China, ${ }^{3}$ Department of Anesthesia, Peking Union Medical College Hospital, Chinese Academy of Medical Sciences and Peking Union \\ Medical College, Beijing 100730, P.R. China, and ${ }^{4}$ Massachusetts General Hospital Center for Translational Pain Research, Department of Anesthesia, \\ Critical Care and Pain Medicine, Massachusetts General Hospital, Harvard Medical School, Charlestown, Massachusetts 02129-2060
}

Postoperative cognitive dysfunction (POCD) is associated with impairments in daily functioning, and increased morbidity and mortality. However, the causes and neuropathogenesis of POCD remain largely unknown. Uncontrolled pain often occurs postoperatively. We therefore set out to determine the effects of surgical incision-induced nociception on the cognitive function and its underlying mechanisms in 3- and 9-month-old mice. The mice had surgical incision in the hindpaw and then were tested for nociceptive threshold, learning, and memory. Brain levels of NMDA receptor and cyclin-dependent kinase 5 (CDK5) were also assessed. We found that surgical incisioninduced nociception in mice led to a decreased freezing time in the tone test (which assesses the hippocampus-independent learning and memory function), but not the context test, of Fear Conditioning System at 3 and $7 \mathrm{~d}$, but not $30 \mathrm{~d}$ post incision in 9-month-old, but not 3-month-old mice. Consistently, the surgical incision selectively decreased synaptic NMDA receptor 2B levels in the medial prefrontal cortex, and increased levels of tumor necrosis factor- $\alpha$ and CDK5 in the cortex, but not hippocampus, of the mice. Finally, eutectic mixture of local anesthetics and CDK5 inhibitor, roscovitine, attenuated the surgical incision-induced reduction in the synaptic NMDA receptor $2 \mathrm{~B}$ levels and learning impairment. These results suggested that surgical incision-induced nociception reduced the synaptic NMDA receptor $2 \mathrm{~B}$ level in the medial prefrontal cortex of mice, which might lead to hippocampus-independent learning impairment, contributing to POCD. These findings call for further investigation to determine the role of surgical incision-induced nociception in POCD.

\section{Introduction}

Postoperative cognitive dysfunction (POCD) (Moller et al., 1998; for review, see Terrando et al., 2011) is associated with increased morbidity and mortality (Monk et al., 2008; Deiner and Silverstein, 2009) and impairments in daily functioning (Phillips-Bute et al., 2006). The causes and neuropathogenesis of POCD remain largely to be determined. More than $80 \%$ of patients who have surgery in the United States have postoperative pain (Apfelbaum et al., 2003). Clinical investigations have shown that pain associated with surgery could contribute to POCD (Wang et al., 2007).

\footnotetext{
Received May 14, 2013; revised 0ct. 2, 2013; accepted Oct. 4, 2013.

Author contributions: B.Y., J.M., and Z.X. designed research; X.Z. and X.X. performed research; Y.D. and Y.Z. contributed unpublished reagents/analytic tools; X.Z. and X.X. analyzed data; Z.X. wrote the paper.

This research was supported by R21AG038994, R01 GM088801, and R01 AG041274 from the National Institutes of Health, Bethesda, Maryland; Investigator-initiated Research grant from Alzheimer's Association, Chicago, Illinois; and Cure Alzheimer's Fund, Wellesley, Massachusetts to Z.X.

${ }^{*}$ X.Z. and X.X. contributed equally to this work.

The authors declare no competing financial interests.

Correspondence should be addressed to Dr. Zhongcong Xie, Associate Professor of Anesthesia, Geriatric Anesthesia Research Unit, Department of Anesthesia, Critical Care and Pain Medicine, Massachusetts General Hospital and Harvard Medical School, 149 13th Street, Room 4310, Charlestown, MA 02129-2060. E-mail: zxie@partners.org.

DOI:10.1523/JNEUROSCI.2049-13.2013

Copyright $\odot 2013$ the authors $\quad 0270-6474 / 13 / 3317737-12 \$ 15.00 / 0$
}

NMDA receptor 2B (NR2B) is involved in learning, memory, and pain (for review, see Qiu et al., 2011). The long-term potentiation activation is dependent on NMDA receptor (Bauer et al., 2002; Berberich et al., 2007; Miwa et al., 2008). Genetic overexpression of NR2B in forebrains causes an enhanced central synaptic potentiation (Tang et al., 1999; Liu et al., 2004). Moreover, NR2B antagonist ifenprodil and Ro25-6981 induce fear conditioning learning impairment (Rodrigues et al., 2001; Dalton et al., 2008). NR2B transgenic mice have enhanced responsiveness to peripheral injection of formalin and complete Freund's adjuvant (Wei et al., 2001), neuropathic pain by transection of spinal nerve induces phosphorylation of NR2B at Tyr1472, and the NR2Bselective antagonist CP-101,606 attenuates the NR2B phosphorylation and the neuropathic pain (Abe et al., 2005). Synaptic- and extrasynaptic NMDA receptors may have different roles in neurological functions (for review, see Hardingham and Bading, 2010). Finally, cyclin-dependent kinase 5 (CDK5; P35 and P25 are its activators) regulates NR2B levels (Sato et al., 2008; Zhang et al., 2008a).

Fear Conditioning System (FCS) can test associative learning and memory, and is among the most commonly used behavioral tests to assess learning and memory function (Satomoto et al., 2009; Cibelli 
et al., 2010; Saab et al., 2010; Terrando et al., 2010). Moreover, context and tone test of FCS can assess the hippocampusdependent and hippocampus-independent learning and memory function, respectively (Kim and Fanselow, 1992; Anagnostaras et al., 1999; Kitamura et al., 2009; Wiltgen et al., 2010). The fear conditioning learning and memory pathway involves the hippocampus, amygdala, and medial prefrontal cortex (] for review, see Maren et al., 2013 and Johansen et al., 2011). The Morris Water Maze (MWM) is another commonly used behavior procedure to assess learning and memory function in rodents.

Our previous study has shown that sleep disturbance, another potential perioperative risk factor of POCD, may selectively induce neuroinflammation in the hippocampus and may lead to hippocampus-dependent learning impairment in the mice (Zhu et al., 2012). However, whether surgical incision-induced nociception can cause neurotoxicity and neurobehavioral deficits in mice is unknown.

Together, we used an established preclinical acute nociception model (Pogatzki and Raja, 2003) in 3-and 9-month-old mice to test a hypothesis that acute nociception following surgical incision increases brain CDK5 levels, which then reduces brain synaptic NR2B levels, leading to learning impairment. We further assessed the effects of surgical incision-induced nociception on NR2B levels in different brain regions (e.g., medial prefrontal cortex vs hippocampus) and the brain region-associated cognitive function in the mice.

\section{Materials and Methods}

Animals. The animal protocol was approved by the Institutional Animal Care and Use Committee at Massachusetts General Hospital, Boston, Massachusetts. Wild-type mice (C57BL/6J, 3 and 9 months old; The Jackson Laboratory) of either sex were randomly assigned to a surgical incision or sham group. The mice were housed in a controlled environment $\left(20-22^{\circ} \mathrm{C} ; 12 \mathrm{~h} \mathrm{light/dark}\right.$ on a reversed light cycle) for 1 week before the studies. The maintenance and handling of mice were consistent with the guideline of National Institutes of Health, and all of the efforts were made to minimize the number of animals in the studies.

Surgical incision. The surgical incision in the right hindpaw of each mouse was made under a brief anesthesia ( $1.4 \%$ isoflurane anesthesia for $3 \mathrm{~min}$ ) as described in a previous study (Pogatzki and Raja, 2003). Briefly, a $0.5 \mathrm{~cm}$ longitudinal incision was made through skin and fascia of the right plantar foot with a number 10 scalpel blade under sterile preparation. The incision was started $0.2 \mathrm{~cm}$ from the proximal edge of the heel and extended distally. The underlying muscle was elevated with curved forceps and incised longitudinally, leaving the muscle origin and insertion intact. Then, the skin overlying the muscle was closed with a 5.0 nylon mattress suture. After the procedure, the mice were allowed to recover in cages with sterile bedding. Control mice underwent a sham procedure that consisted of anesthesia and sterile preparation but without the incision.

Drug treatments. Eutectic mixture of local anesthetics (EMLA) cream ( $2.5 \%$ lidocaine and $2.5 \%$ prilocaine) was applied on the wound in the

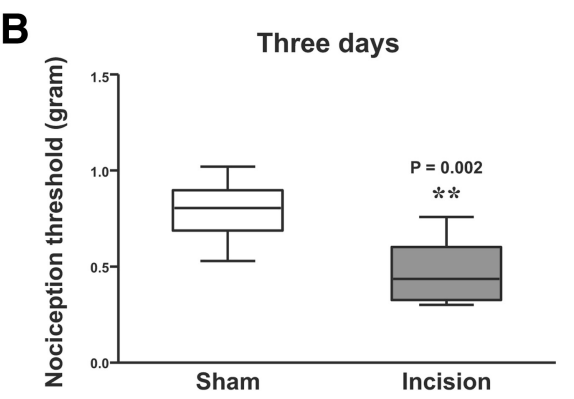

D

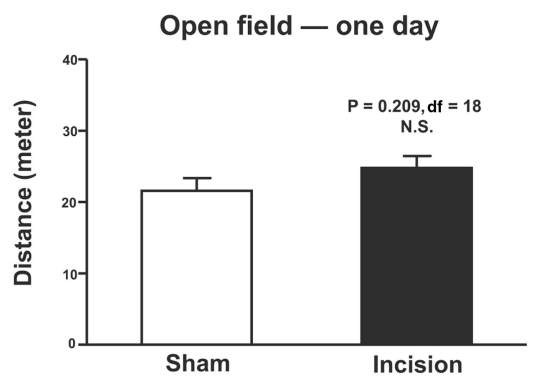

Figure 1. Surgical incision in mice hindpaw induces nociception in the mice. $\boldsymbol{A}$, The surgical incision (black bar) reduces the nociception threshold of the mice as compared with the sham condition (white bar) at $1 \mathrm{~d}$ after the incision. $\boldsymbol{B}$, The surgical incision (black bar) reduces the nociception threshold of the mice as compared with the sham condition (white bar) at $3 \mathrm{~d}$ after the incision. (black bar) does not significantly affect the speed of movement of the mice in the open field test as compared with the sham condition (white bar) at $1 \mathrm{~d}$ after the incision. $N=5-10$.

paw (surgical incision group) or just the paw (control group) as analgesia every $8 \mathrm{~h}$ for 1 week post incision for the mice in the EMLA treatment group. To apply the cream, each mouse was allowed to walk through the EMLA cream, thus EMLA was attached to each paw of the mouse, including the hindpaw with the surgical incision. The control condition of EMLA in the current study was no EMLA treatment. Roscovitine (R-1234; LC Laboratories) $10 \mathrm{mg} / \mathrm{kg}$ or equal volume vehicle (sterile oil with $0.2 \%$ dimethylsulfoxide) was injected through intraperitoneal route daily for $3 \mathrm{~d}$ post incision in the interaction studies.

Open field test. Locomotor activity was tested in the open field as described in a previous study (Weaver et al., 2006) with modification. Briefly, the mice were placed directly into one corner of the open field $(120 \times 120 \mathrm{~cm})$, which was divided into a grid of $3 \times 3$ squares. Movement of the animal in the area was recorded during a $10 \mathrm{~min}$ testing session. The total distance traveled and mean speed were recorded and quantified by Any-Maze (Stoelting).

Nociception threshold determination. Nociception threshold was determined by using nylon von Frey filaments as described in a previous study (Chaplan et al., 1994). Mice were placed on a wire mesh platform in clear cylindrical plastic enclosures $(8 \mathrm{~cm}$ diameter and $10 \mathrm{~cm}$ in height). After $20 \mathrm{~min}$ of stay on the platform, the filaments were applied (bending force range from $0.008-26 \mathrm{~g}$; North Coast Medical) on the wound edge of the incised hindpaw for $\sim 5 \mathrm{~s}$ with a $10 \mathrm{~s}$ interval between each stimulation. Withdrawal of the hindpaw from the floor was scored as a positive re- 
A Tone - three days (pairing after incision)

$\mathbf{B}_{\mathrm{C}}$

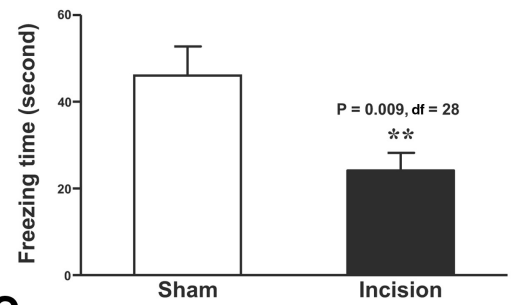

C Tone -7 days (pairing after incision)

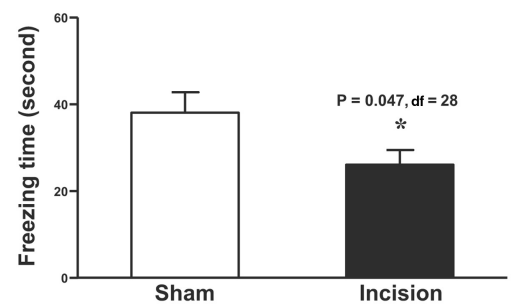

E

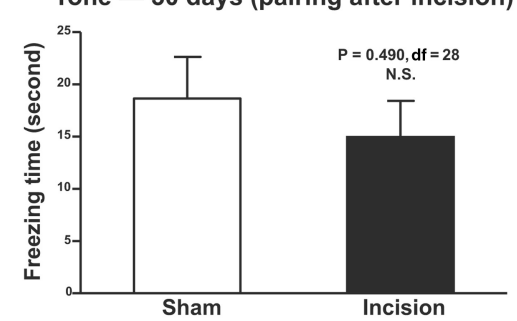

G Tone - one day (pairing before incision)

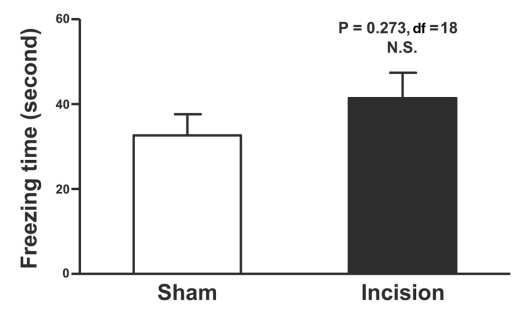

I Tone - five days (pairing before incision)
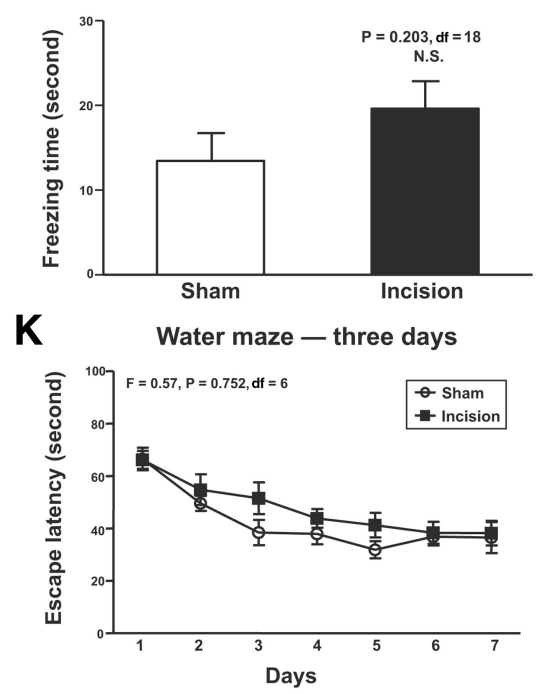

B Context - three days (pairing after incision)

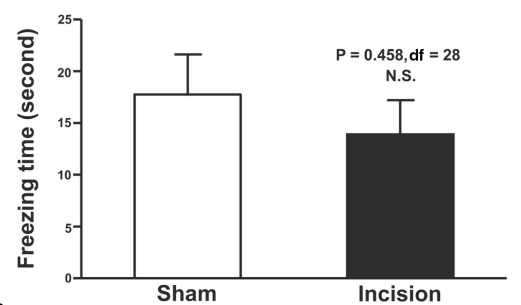

D
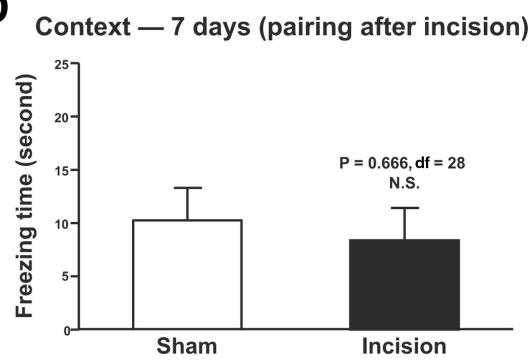

$\mathbf{F}$

F Context $\mathbf{- 3 0}$ days (pairing after incision)

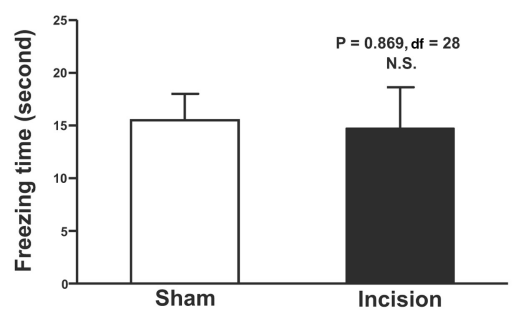

H Context - one day (pairing before incision)

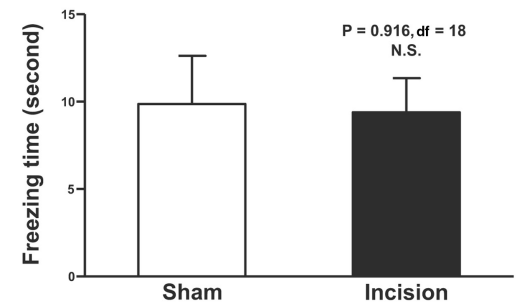

J Context - five days (pairing before incision)

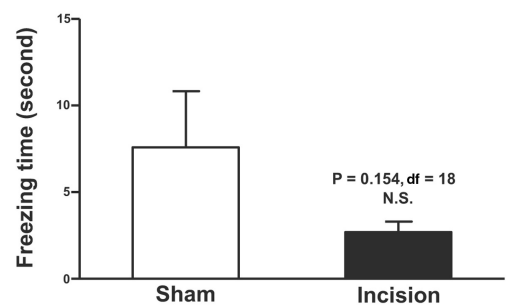

L

Water maze - three days

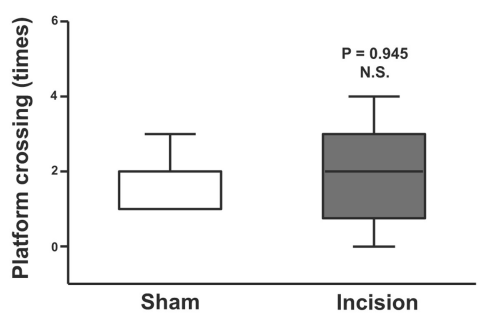

Figure 2. Surgical incision in mice hindpaw induces a learning impairment in learning new things in the mice. $A$, The surgical incision decreases freezing time in the tone test of the FCS as compared with the sham condition at $3 \mathrm{~d}$ post incision in the mice. $\boldsymbol{B}$, The surgical incision does not decrease freezing time in the context test of the FCS as compared with the sham condition at $3 \mathrm{~d}$ post incision in the mice. C, The surgical incision decreases freezing time in the tone test of the FCS as compared with the sham condition

sponse. When no response was obtained, the next stiffer filament in the series was applied to the same paw. Each monofilament was applied in the hindpaw five times. The hindpaw withdrawal threshold or the nociception threshold was obtained as the force (in grams) at which foot withdrawal occurred at least three of the five stimulations.

FCS. FCS has been often used to detect associative learning and memory function induced by anesthesia alone (Saab et al., 2010; Zhang et al., 2012), anesthesia with surgery (Terrando et al., 2010; Wan et al., 2010), and sleep disturbance (Zhu et al., 2012). We performed the FCS experiments as described in our previous studies (Zhang et al., 2012; Zhu et al., 2012) and other studies (Saab et al., 2010; Terrando et al., 2010). Specifically, different groups of mice were exposed for training in the FCS (Stoelting) $24 \mathrm{~h}$ before and after the surgical incision, respectively. Each mouse was allowed to explore the chamber for $180 \mathrm{~s}$ before presentation of a $2 \mathrm{~Hz}$ pulsating tone $(80 \mathrm{~dB}, 1500 \mathrm{~Hz})$ that persisted for $60 \mathrm{~s}$. The tone was followed immediately by a mild foot shock $(0.8 \mathrm{~mA}$ for $0.5 \mathrm{~s}$ ). Context (no tone period) and tone (tone period) learning and memory were probed at 3,7 , and $30 \mathrm{~d}$ post incision in sequence. The mice were tested in the context test first, then in the tone test $1 \mathrm{~h}$ later. For the context test, each mouse (from either the control group or surgical incision group) was allowed to stay in the chamber for $180 \mathrm{~s}$, followed by another $180 \mathrm{~s}$ period without a tone, and finally $30 \mathrm{~s}$ for recovery. For the tone test, each mouse (from either the control group or surgical incision group) was allowed to stay in the chamber for $180 \mathrm{~s}$, followed by another $180 \mathrm{~s}$ period with a tone, and finally $30 \mathrm{~s}$ for recovery. Learning and memory function was assessed by measuring the amount of time the mouse demonstrated "freezing behavior," defined as a completely immobile posture except for respiratory efforts, during the test period (the second $180 \mathrm{~s}$ period), which was analyzed by Any-Maze software (Stoelting). The first $180 \mathrm{~s}$ period allowed mice to adjust for the environment before the counting of freezing time in the second 180 s period.

\section{$\leftarrow$}

at 7 d post incision in the mice. $\boldsymbol{D}$, The surgical incision does not decrease freezing time in the context test of the FCS as compared with the sham condition at $7 \mathrm{~d}$ post incision in the mice. $\boldsymbol{E}$, The surgical incision does not decrease freezing time in the tone test of the FCS as compared with the sham condition at $30 \mathrm{~d}$ post incision in the mice. $\boldsymbol{F}$, The surgical incision does not decrease freezing time in the context test of the FCS as compared with the sham condition at $30 \mathrm{~d}$ post incision in the mice. Interestingly, when the pairing of mice in the FCS was performed at $1 \mathrm{~d}$ before the incision (aiming to assess whether nociception could prevent mice from remembering old tasks), the incision does not reduce freezing time of mice in tone test $(\boldsymbol{G})$ and context test $(\boldsymbol{H})$ of $\mathrm{FCS}$ at $1 \mathrm{~d}$ post incision, and at $5 \mathrm{~d}$ post incision in tone test $(\boldsymbol{I})$ and context test $(\boldsymbol{l})$ of FCS. The surgical incision does not increase the escape latency $(\boldsymbol{K})$ and does not decrease the platform crossing times $(\boldsymbol{L})$ in the MWM test as compared with the sham condition in the mice. $N=15$. 
MWM. MWM was performed as previously described (Bianchi et al., 2008) to assess spatial learning and memory function. Briefly, all mice were trained to swim to a hidden platform in four trials per day for $7 \mathrm{~d}$ (day 1-7) at $3 \mathrm{~d}$ after the surgical incision. The mice were given $90 \mathrm{~s}$ to find the platform and allowed to stay for $10-15$ s before being removed from the pool. If a mouse could not find the platform within $90 \mathrm{~s}$, it was gently guided to the platform and allowed to remain there for $10-15 \mathrm{~s}$. The platform was placed in the target quadrant for all trials, but the starting points were random for each mouse. We trained the mice by using a cue on the wall (cued training). We measured the time it took for each mouse to reach the platform (escape latency) and used this as the learning score. On the seventh day, we also tested the memory of each mouse by removing the platform and measuring the number of times the mouse crossed the platform area with the same cue to obtain the memory score. We compared the learning and memory score and swimming speed between the mice in the surgical incision group and sham group.

Brain tissue harvest and protein level quantification. Three and seven days post incision, the mice were killed by decapitation. The brain cortex (medial prefrontal cortex, lateral prefrontal cortex, and cingulate cortex), hippocampus, and amygdala were harvested separately. For the Western blot analysis, the harvested brain cortex, hippocampus, or amygdala was homogenized on ice using immunoprecipitation buffer $(10 \mathrm{~mm}$ Tris-HCl, pH 7.4, 150 mm NaCl, 2 mm EDTA, and $0.5 \%$ Nonidet P-40) plus protease inhibitors

( $1 \mu \mathrm{g} / \mathrm{ml}$ aprotinin, $1 \mu \mathrm{g} / \mathrm{ml}$ leupeptin, and $1 \mu \mathrm{g} / \mathrm{ml}$ pepstatin A). The lysates were collected, centrifuged at $12,000 \mathrm{rpm}$ for $10 \mathrm{~min}$, and quantified for total proteins with Bicinchoninic Acid protein assay kit (Pierce).

Separation of synaptic and extrasynaptic membranes. The separation of synaptic and extrasynaptic fractions was performed as described in previous studies (Goebel-Goody et al., 2009; Li et al., 2011) with modifications. The separation was based on the principle that the postsynaptic density (PSD) protein-associated or synaptic fraction is insoluble in Triton X-100, but the non-PSD protein-associated or extrasynaptic fraction is soluble in Triton X-100. All of the following procedures were conducted at $4^{\circ} \mathrm{C}$ to minimize enzymatic activity. The harvested brain tissues were put in an ice-cold sucrose homogenization buffer containing the following (in mM): 320 sucrose, 10 Tris, $\mathrm{pH} 7.4,1 \mathrm{Na} 3 \mathrm{VO} 4,5 \mathrm{NaF}, 1$ EDTA, and 1 EGTA. The tissues were then homogenized in a glass grinding vessel using a rotating Teflon pestle $(2000 \mathrm{rpm})$ with at least 12 passes to create a dounce homogenate. The dounce homogenate was centrifuged at $1000 \mathrm{~g}$ for $10 \mathrm{~min}$ to remove nuclei and incompletely homogenized material (P1). The resulting supernatant (S1) was spun at $10,000 \mathrm{~g}$ for 15 min to obtain a P2. The P2 was subsequently resuspended in $120 \mu \mathrm{l}$ sucrose buffer using a Fisher Vortex (Fisher Scientific). The P2 was then subjected to detergent extraction by adding eight volumes of a nonionic detergent Triton X-100 buffer (final: $0.5 \%$ volume/volume) containing the following reagents (in mM): 10 Tris, $\mathrm{pH} 7.4,1 \mathrm{Na} 3 \mathrm{VO} 4,5 \mathrm{NaF}, 1 \mathrm{~mm}$ EDTA, and 1 EGTA, which was described in a previous study (Cotman and Taylor, 1972). This suspension was incubated at $4^{\circ} \mathrm{C}$ for $20 \mathrm{~min}$ with gentle rotation and then centrifuged at 32,000 $\mathrm{g}$ for $20 \mathrm{~min}$. We operationally defined the pellet as the PSD protein-associated or synaptic fraction and the supernatant as the non-PSD protein-associated or extrasynaptic fraction, based on the fact that synaptic fraction, which is bound to PSD proteins, is not soluble in Triton X-100. For every centrifugation step above, the pellets were rinsed twice with sucrose buffer to avoid potential contamination between fractions. Final pellets (synaptic fraction) were resuspended in sucrose buffer, and proteins were solubi-
B

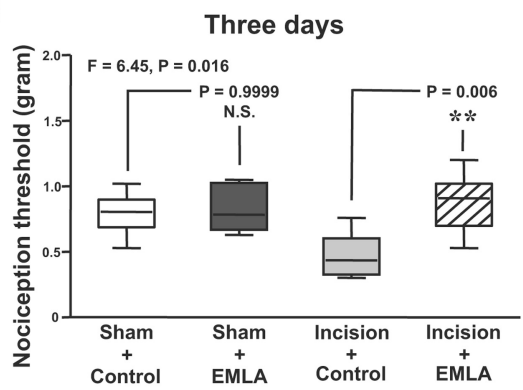

)

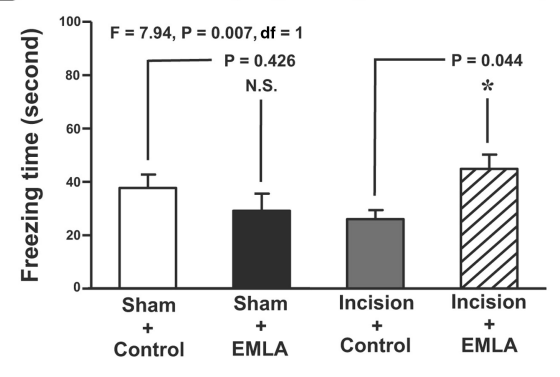


A

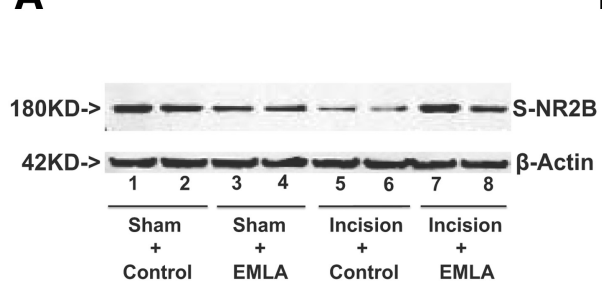

C

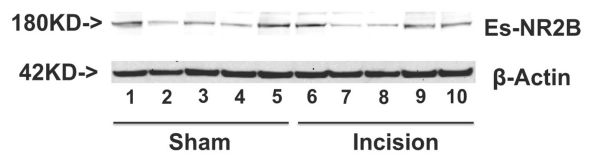

E

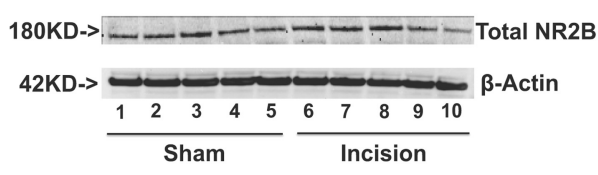

G

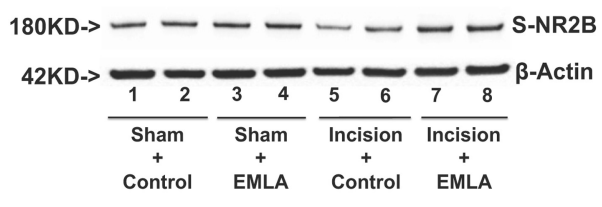

I

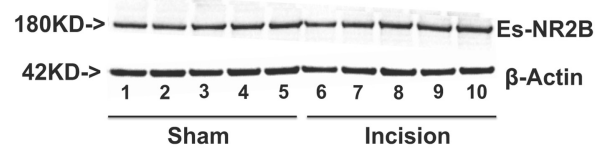

B
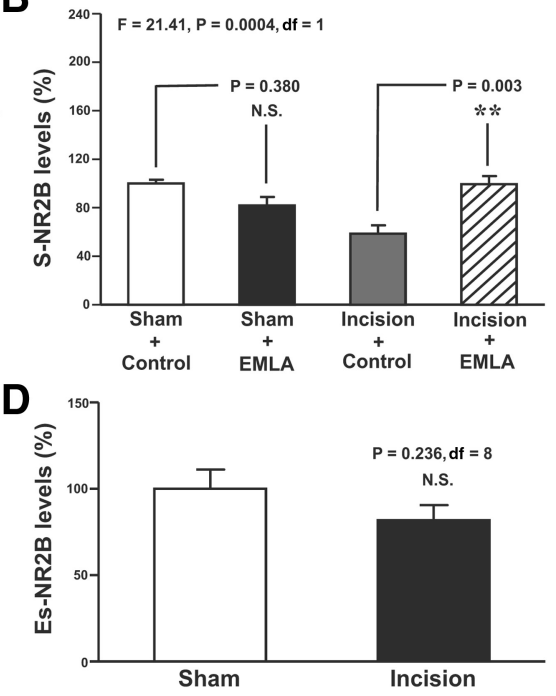

$\mathbf{F}$
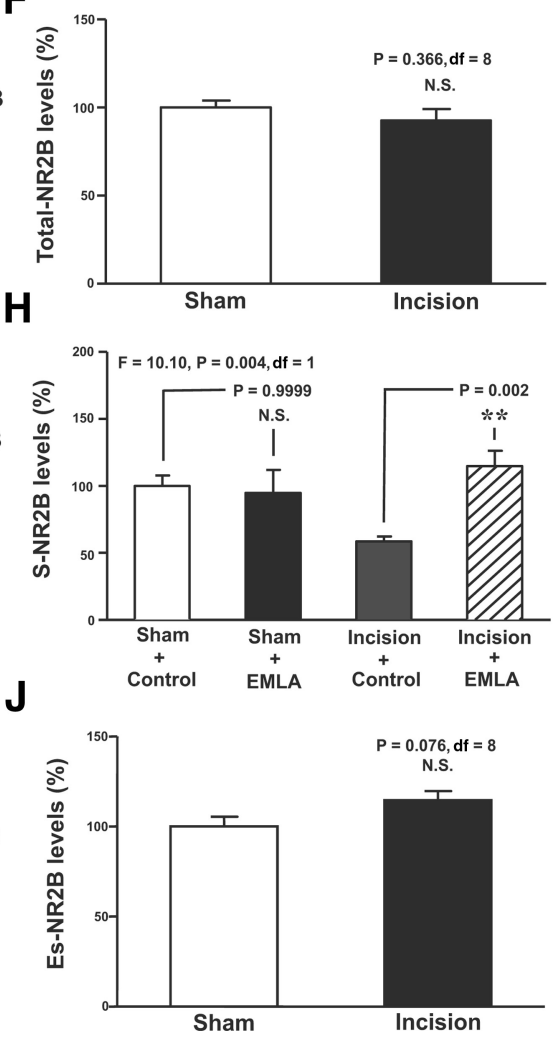

Figure 4. Surgical incision in mice hindpaw reduces S-NR2B levels in the medial prefrontal cortex of mice. $\boldsymbol{A}$, The surgical incision (lanes 5 and 6 ) decreases the levels of S-NR2B in the cortex of mice as compared with sham condition (lanes 1 and 2) in the Western blot analysis. EMLA itself (lanes 3 and 4 ) does not increase the levels of S-NR2B in the cortex of mice as compared with the control condition (lanes 1 and 2), but the EMLA treatment attenuates the surgical incision-induced reduction in the S-NR2B levels in the cortex of mice (lanes 7 and 8 ) in the Western blot analysis. $\boldsymbol{B}$, Quantification of the Western blot shows that the surgical incision (gray bar) decreases the S-NR2B levels as compared with sham condition (white bar). EMLA itself (black bar) does not increase the levels of S-NR2B in the cortex of mice as compared with the control condition (white bar), but the EMLA treatment attenuates the surgical incision-induced reduction in the S-NR2B levels (net bar) in the mice. C, The surgical incision (lanes 6-10) does not decrease the levels of Es-NR2B in the cortex of mice as compared with the sham condition (lanes 1-5) in the Western blot analysis. D, Quantification of the Western blot shows that the surgical incision (black bar) does not decrease the Es-NR2B levels as compared with the sham condition (white bar). $\boldsymbol{E}$, The surgical incision (lanes $6-10$ ) does not decrease the levels of total NR2B in the cortex of mice as compared with the sham condition (lanes 1-5) in the Western blot analysis. F, Quantification of the Western blot shows that the surgical incision (black bar) does not decrease the total NR2B levels as compared with the sham condition (white bar). G, The surgical incision (lanes 5 and 6) decreases the levels of S-NR2B in the medial prefrontal cortex of mice as compared with sham condition (lanes 1 and 2) in the Western blot analysis. EMLA itself (lanes 3 and 4 ) does not increase the levels of S-NR2B in the medial prefrontal cortex of mice as compared with control condition (lanes 1 and 2), but the EMLA treatment

ANOVA) was used after data were ranked within their respective block. Normally distributed data were expressed as mean \pm SD and analyzed by using parametric analysis. These data included distance and speed in the open field studies, freezing time in the FCS studies, escape latency in the MWM studies, and protein amounts in the quantitative Western blotting studies (levels of S-NR2B, Es-NR2B, total NR2B, P35, P25, and tumor necrosis factor (TNF)- $\alpha$ ). Student's $t$ test was used to analyze the difference between sham and incision, and treatment with control, EMLA, and roscovitine. Two-way ANOVA was used to analyze the interaction of EMLA or roscovitine. Post hoc Bonferroni test was used to determine the potential difference between EMLA or roscovitine and control under sham or incision condition. The number of samples varied from 5 to $15 ; p$ values $<0.05$ or 0.01 were considered statistically significant. Degree of freedom from parametric data analysis was calculated and presented. The significance testing was two tailed, and Prism 6 software and SAS (SAS Institute) software (version 9.2) were used to analyze the data.

\section{Results}

Surgical incision in the hindpaw of mice induced nociception in the mice We used an established preclinical model in mice (Pogatzki and Raja, 2003) to assess whether surgical incision in the hindpaw of mice can induce nociception, leading to neurotoxicity and neurobehavioral deficits. We found that the surgical incision reduced nociception threshold as compared with the sham condition at $1 \mathrm{~d}$ [Fig. $1 A$; $0.31(0.28-0.31)$, median and interquartile range (25-75\%), vs $0.69(0.64-$ $0.76),{ }^{* *} p=0.0002$ ] and $3 \mathrm{~d}$ [Fig. $1 B ; 0.57$ $(0.46-0.70)$ vs $0.88(0.83-0.95),{ }^{\star} p=$ 0.002 ], but not $7 \mathrm{~d}$ [Fig. $1 C ; 0.80(0.75-$ $0.83)$ vs $0.78(0.69-0.82), p=0.917, \mathrm{NS}]$, post incision in the mice. We also found that the surgical incision did not significantly affect the distance (Fig. 1D) and the

\section{$\leftarrow$}

attenuates the surgical incision-induced reduction in the S-NR2B levels in the medial prefrontal cortex of mice (lanes 7 and 8 ) in the Western blot analysis. $\boldsymbol{H}$, Quantification of the Western blot shows that the surgical incision (gray bar) decreases the S-NR2B levels as compared with sham condition (white bar). EMLA itself (black bar) does not increase the levels of S-NR2B in the medial prefrontal cortex of mice as compared with the control condition (white bar), but the EMLA treatment attenuates the surgical incision-induced reduction in the S-NR2B levels (net bar) in the medial prefrontal cortex of mice. I, The surgical incision (lanes 6-10) does not decrease the levels of Es-NR2B in the medial prefrontal cortex of mice as compared with the sham condition (lanes 1-5) in the Western blot analysis. J, Quantification of the Western blot shows that the surgical incision (black bar) does not decrease the Es-NR2B levels in the medial prefrontal cortex of mice as compared with the sham condition (white bar). $N=6-8$. 
speed of movement of the mice (Fig. 1E) in the open field test as compared with the sham condition at $1 \mathrm{~d}$ post incision. These data suggested that the surgical incision in the hindpaw of mice was able to induce nociception in the mice without impairment of locomotor activity.

\section{The surgical incision induced hippocampus-independent learning impairment in the mice}

Next, we investigated whether the surgical incision might induce learning impairment in the mice in the FCS. The pairing of FCS was performed $1 \mathrm{~d}$ after the surgical incision. The surgical incision reduced the freezing time of mice in the tone test of FCS at $3 \mathrm{~d}$ (Fig. 2A; $24.17 \pm 15.76$ vs $46.09 \pm 25.92,{ }^{\star *} p=$ 0.009 ) and $7 \mathrm{~d}$ (Fig. 2C; $26.08 \pm 13.24 \mathrm{vs}$ $\left.38.10 \pm 18.03,{ }^{\star} p=0.047\right)$, but not $30 \mathrm{~d}$ (Fig. $2 E ; 14.98 \pm 3.46$ vs $18.66 \pm 3.98$, $p=0.490$, NS) post incision. The surgical incision did not reduce the freezing time of mice in the context test of FCS at $3 \mathrm{~d}$ (Fig. $2 B ; p=0.458$, NS), 7 d (Fig. 2D; $p=0.666$, NS), and $30 \mathrm{~d}$ (Fig. $2 F ; p=$ 0.869 , NS) post incision. The tone and context test of the FCS have been reported to assess hippocampus-independent and hippocampus-dependent learning and memory function, respectively (Kim and Fanselow, 1992; Anagnostaras et al., 1999; Kitamura et al., 2009; Wiltgen et al., 2010). Therefore, these data suggested that the surgical incision in the hindpaw of mice induced hippocampus-independent learning impairment, which was detected by the tone test of FCS. In a different experiment, the pairing of FCS was performed $1 \mathrm{~d}$ before the surgical incision. In these studies, the surgical incision did not induce learning impairment in the mice (Fig. $2 G-J)$. Together, these results suggested that the surgical incision-induced nociception could cause fearing learning impairment, i.e., impairing the mice from learning new tasks; but not fear extinction impairment, i.e., not impairing the mice from remembering old tasks.

In addition, we assessed the effects of the surgical incision on cognitive function in the MWM. We found that the surgical incision did not increase the escape latency (Fig. $2 K$ ), did not reduce the platform crossing times in MWM (Fig. 2L), and did not alter swimming speed (data not shown). These data suggested that the surgical incision might not induce spatial learning and memory impairment in the mice.

\section{The surgical incision-induced learning impairment was dependent on the surgical incision-induced nociception in the mice}

Given that the surgical incision induced nociception and learning impairment in the mice, next we asked whether the surgical incision-induced learning impairment was dependent on the
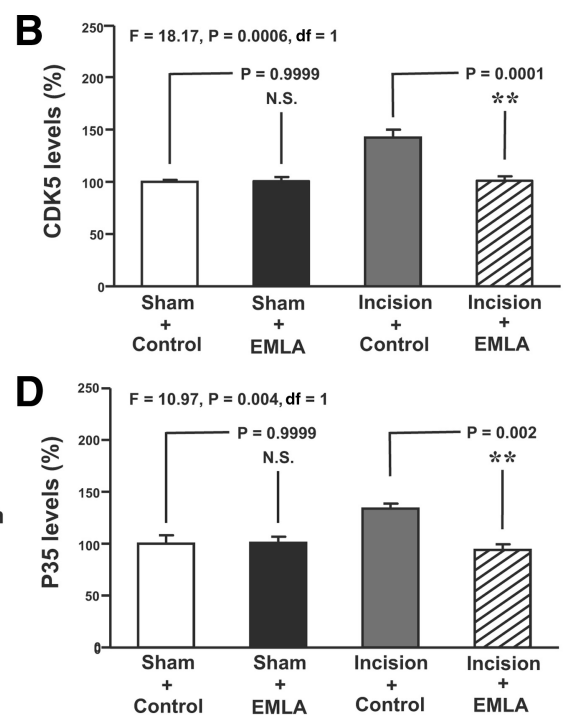

Figure 5. Surgical incision in mice hindpaw increases levels of CDK5, P35, and P25 in the cortex of mice. $\boldsymbol{A}$, The surgical incision (lanes 5 and 6 ) increases the levels of CDK5 in the cortex of mice as compared with the sham condition (lanes 1 and 2) in the Western analysis. EMLA itself (lanes 3 and 4) does not decrease the levels of CDK5 in the cortex of mice as compared with the contro (b) sham condition (white bar). EMLA itself (black bar) does not decrease the levels of CDK5 (hite bar), but the EMLA treatment attenuates the surgical incisionof mice as compared with the sham condition (lanes 1 and 2) in the Western blot analysis. EMLA itself (lanes 3 and 4 ) does not ex of mice as compared with the control condition (white bar), but the EMLA treatment attenuates the surgical incisioninduced increase in the P35 and P25 levels (net bar). $N=6$.

surgical incision-induced nociception in the mice. We used local anesthetic cream EMLA (2.5\% lidocaine and 2.5\% prilocaine) in the interaction studies. We were able to show that there was a significant interaction between surgical incision and EMLA treatment, and that the treatment with EMLA attenuated the surgical incision-induced reduction in the nociception threshold in the mice at $8 \mathrm{~h}$ (Fig. $3 A ; F=4.72, p=0.037$, Friedman nonparametric two-way ANOVA; ${ }^{* *} p=0.001$, Kruskal-Wallis nonparametric ANOVA post hoc Dunn test) and $3 \mathrm{~d}$ post incision (Fig. 3B; $F=6.45, p=0.016$, Friedman nonparametric two-way ANOVA; ${ }^{*} p=0.006$, Kruskal-Wallis nonparametric ANOVA post hoc Dunn test). Moreover, two-way ANOVA showed that there was a significant interaction of the surgical incision and EMLA in the tone test of FCS at $3 \mathrm{~d}$ (Fig. $3 C ; F=6.19, p=0.017, \mathrm{df}=1$ ) and $7 \mathrm{~d}$ (Fig. $3 D ; F=7.94, p=0.007, \mathrm{df}=1$ ) post incision. Post hoc Bonferroni test showed that whereas EMLA treatment alone did not significantly change the freezing time of the tone test of FCS as compared with control condition (Fig. $3 C ; p=0.9999$, NS; Fig. $3 D ; p=0.426, \mathrm{NS})$, the EMLA treatment attenuated the surgical 
A

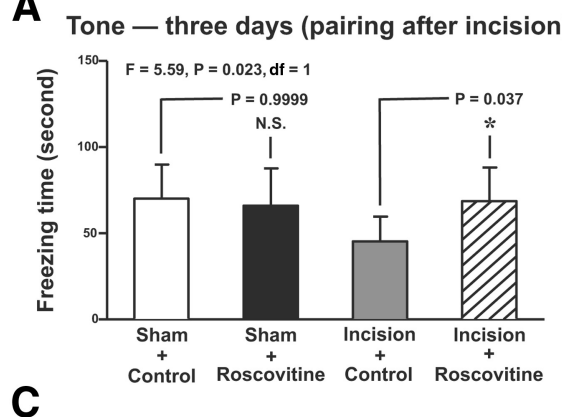

C

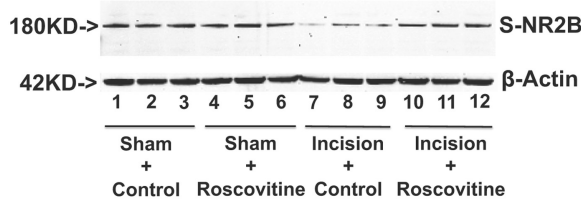

B Tone -7 days (pairing after incision)

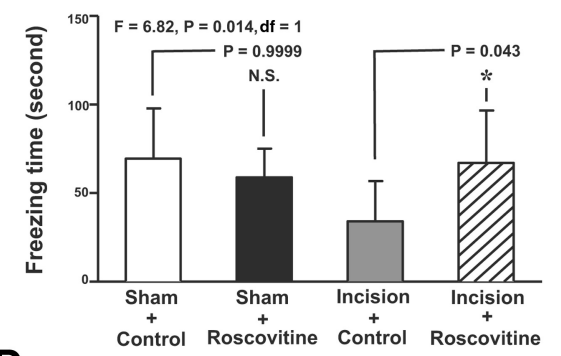

D

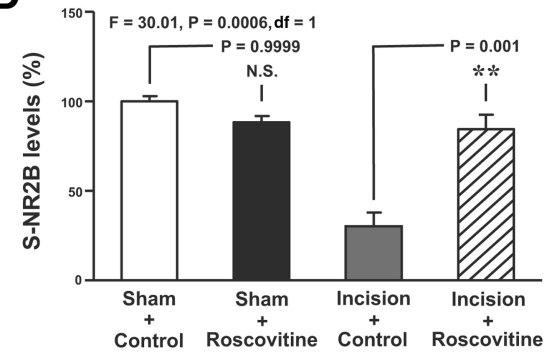

Figure 6. Roscovitine attenuates the surgical incision-induced learning impairment and reduction in the levels of S-NR2B in cortex of mice. $\boldsymbol{A}$, The surgical incision (gray bar) decreases freezing time in the tone test of the FCS as compared with the sham condition (white bar) at $3 \mathrm{~d}$ post incision in the mice. Roscovitine (net bar) attenuates the surgical incision-induced reduction in freezing time in the tone test of the FCS. $\boldsymbol{B}$, The surgical incision (gray bar) decreases freezing time in the tone test of the FCS as compared with the sham condition (white bar) at $7 \mathrm{~d}$ post incision in the mice. Roscovitine (net bar) attenuates the surgical incision-induced reduction in freezing time in the tone test of the FCS. C, The surgical incision (lanes 7-9) decreases levels of S-NR2B in the cortex of mice as compared with the sham condition (lanes 1-3) in the Western blot analysis. Roscovitine itself (lanes $4-6$ ) does not increase the levels of S-NR2B in the cortex of mice as compared with the control condition (lanes 1-3), but roscovitine attenuates the surgical incision-induced reduction in the S-NR2B levels in the cortex of mice (lanes 10-12) in the Western blot analysis. D, Quantification of the Western blot shows that the surgical incision (gray bar) decreases the S-NR2B levels as compared with the sham condition (white bar). Roscovitine itself (black bar) does not increase the levels of S-NR2B in the cortex of mice as compared with control condition (white bar), but the roscovitine treatment attenuates the surgical incision-induced reduction in the S-NR2B levels (net bar). $N=6$.
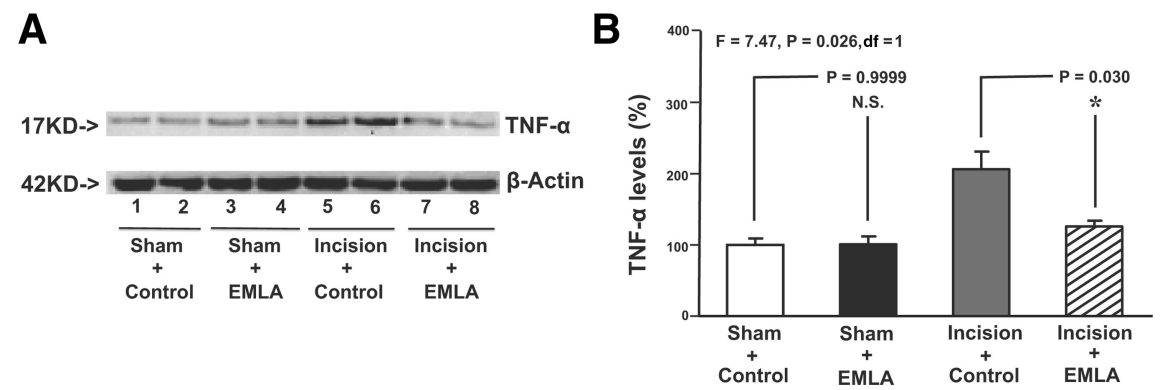

Figure 7. Surgical incision in mice hindpaw increases TNF- $\alpha$ levels in the cortex of mice. $A$, The surgical incision (lanes 5 and 6 ) increases levels of TNF- $\alpha$ in the cortex of mice as compared with the sham condition (lanes 1 and 2) in the Western blot analysis. EMLA itself (lanes 3 and 4 ) does not decrease the levels of TNF- $\alpha$ in the cortex of mice as compared with the control condition (lanes 1 and 2), but the EMLA treatment attenuates the surgical incision-induced elevation in the TNF- $\alpha$ levels in the cortex of mice (lanes 7 and 8 ) in the Western blot analysis. $\boldsymbol{B}$, Quantification of the Western blot shows that the surgical incision (gray bar) increases TNF- $\alpha$ levels as compared with the sham condition (white bar). EMLA itself (black bar) does not decrease the levels of TNF- $\alpha$ in the cortex of mice as compared with the control condition (white bar), but the EMLA treatment attenuates the surgical incisioninduced increase in the TNF- $\alpha$ levels (net bar). $N=6$.

incision-induced reduction in the freezing time of the tone test of FCS as compared with control condition (Fig. $3 C$; ${ }^{* *} p<0.0001$; Fig. $\left.3 D ;{ }^{\star} p=0.044\right)$. The EMLA-treated incision mice had a higher nociception threshold (Fig. $3 A, B$ ) and more freezing time (Fig. $3 C, D$ ) as compared with the control-treated incision mice. These findings suggested that the surgical incision-induced learning impairment was dependent on the surgical incisioninduced nociception in the mice.
The surgical incision-induced nociception reduced synaptic NR2B levels and increased the levels of CDK5, $\mathrm{P} 35$, and $\mathrm{P} 25$ in mice cortex

Synaptic NR2B (S-NR2B) has been shown to be involved in both cognitive function and pain (for review, see Hardingham and Bading, 2010; Zhou and Sheng, 2013), we therefore assessed the effects of surgical incision-induced nociception on the S-NR2B levels. Immunoblotting of S-NR2B showed that there were visible reductions in the bands representing S-NR2B in the cortex of mice following the surgical incision as compared with the sham condition (Fig. 4A). Moreover, the surgical incision-induced reductions in S-NR2B levels were attenuated by the treatment of EMLA (Fig. 4A). There was no significant difference in the $\beta$-actin levels among these treatments (Fig. 4A). The quantification of the Western blot, based on the ratio of S-NR2B to $\beta$-actin, showed that there was a significant interaction between the surgical incision and the EMLA treatment on S-NR2B levels, and that the EMLA treatment attenuated the surgical incision-induced reduction in S-NR2B levels in mice cortex (Fig. $4 B ; F=21.41, p=0.0004$, df $=1$ ). Post hoc Bonferroni test showed that whereas EMLA treatment alone did not significantly change the S-NR2B levels as compared with control condition (Fig. $4 B ; p=0.380$, NS), the EMLA treatment attenuated the surgical incision-induced reduction in the S-NR2B levels as compared with control condition (Fig. 4B; $\left.{ }^{\star} p=0.003\right)$. The surgical incision did not reduce extrasynaptic NR2B (Es-NR2B) levels in the cortex of mice (Fig. $4 C, D$ ). Finally, the surgical incision did not significantly affect the total NR2B levels in mice cortex (Fig. 4E, F).

Next, we assessed the effects of the surgical incision on the NR2B levels in specific brain regions. We found that the surgical incision decreased the S-NR2B levels in medial prefrontal cortex (Fig. $4 G, H)$, but not in lateral prefrontal cortex, cingulate cortex, and amygdala (data not shown) of the mice. Moreover, the surgical incision-induced reductions in S-NR2B levels were attenuated by the treatment of EMLA (Fig. 4G,H; $F=10.10$, $p=0.004, \mathrm{df}=1,{ }^{* *} p=0.002$, two-way ANOVA and post hoc Bonferroni test). Finally, the surgical incision did not reduce EsNR2B levels in medial prefrontal cortex (Fig. 4I,J). These data suggested that the surgical incision-induced nociception could reduce S-NR2B (but not Es-NR2B) levels in specific brain regions (e.g., medial prefrontal cortex but not cingulate cortex).

CDK5 has been shown to regulate NR2B levels (Sato et al., 2008; Zhang et al., 2008a), and both P35 and P25 are activators of 
CDK5 (Patrick et al., 1999; Kusakawa et al., 2000; Lee et al., 2000; Cruz et al., 2003; Asada et al., 2008). We were able to show that the surgical incision increased the levels of CDK5, P35, and P25 in the cortex (entire cortex; Fig. $5 \mathrm{~A}, \mathrm{C}$ ) of mice at $3 \mathrm{~d}$ post incision in the Western blot analysis (Fig. $5 A, C$ ). The EMLA treatment attenuated the surgical incision-induced elevation of CDK5, P35, and P25 levels in the cortex (entire cortex) of mice (Fig. $5 A, C$ ). There was no significant difference in the $\beta$-actin levels of these treatments (Fig. $5 A, C)$. The quantification of the Western blots, based on the ratio of CDK5, P35, and $\mathrm{P} 25$ to $\beta$-actin, showed that there was a significant interaction between the surgical incision and the EMLA treatment (Fig. $5 B ; F=18.17, p=0.0006$, df $=1$; Fig. $5 D ; F=10.97, p=0.004, \mathrm{df}=1$; Fig. $5 E ; F=19.44, p=0.0004, \mathrm{df}=1$, twoway ANOVA). Post hoc Bonferroni test showed that whereas EMLA treatment alone did not significantly change the levels of CDK5 (Fig. 5B), P35 (Fig. 5D), and P25 (Fig. 5E) as compared with control condition, the EMLA treatment attenuated the surgical incision-induced increases in the levels of CDK5 (Fig. $5 B$ ), P35 (Fig. 5D), and P25 (Fig. 5E) as compared with control condition. The EMLAtreated incision mice had lesser levels of CDK5 (Fig. 5B), P35 (Fig. 5D), and P25 (Fig. $5 E$ ) as compared with the controltreated incision mice. These data suggested that the surgical incision could decrease S-NR2B levels and increase the levels of CDK5, P35, and P25 in the cortex of mice, and such effects were dependent on the surgical incision-induced nociception.

\section{CDK5 inhibitor roscovitine mitigated the surgical incision- induced learning impairment and reduction in synaptic NR2B levels in mice cortex}

Given that the surgical incision increased the levels of CDK5 (as well as P35 and P25), reduced S-NR2B levels in the mice cortex, and caused learning impairment in the mice, next, we determined whether CDK5 inhibitor roscovitine could ameliorate these effects of the surgical incision. Two-way ANOVA and post hoc Bonferroni test showed that there was a significant interaction between the surgical incision and the roscovitine treatment (Fig. $6 A ; F=5.59, p=0.023$, df $=1$; Fig. $6 B ; F=6.82, p=0.014$, $\mathrm{df}=1$ ), and that the roscovitine treatment ameliorated the surgical incision-induced reduction in freezing time of mice in tone test of FCS at $3 \mathrm{~d}$ (Fig. $6 A ;{ }^{\star} p=0.037$ ) and $7 \mathrm{~d}$ (Fig. $6 B ;{ }^{*} p=$ 0.043 ) post incision. Moreover, quantitative Western blot showed that the roscovitine treatment attenuated the surgical incision-induced reduction in the S-NR2B levels in the cortex of mice (Fig. 6C, $D ; F=30.01, p=0.0006$, $\mathrm{df}=1,{ }^{\star *} p=0.001$, two-way ANOVA and post hoc Bonferroni test). The roscovitinetreated incision mice had more freezing times (Fig. 6A,B) and higher levels of S-NR2B (Fig. 6D) as compared with the controltreated incision mice. These data suggest that the surgical incision-induced learning impairment and reduction in S-NR2B
B

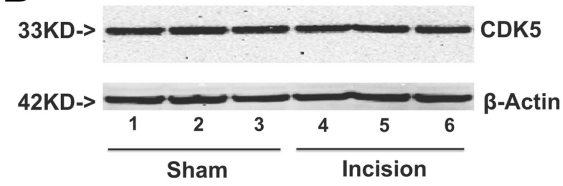

D

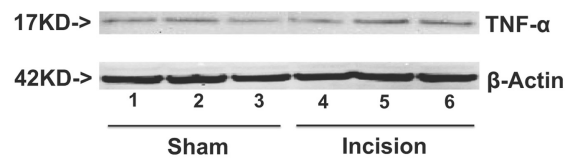

Figure 8. Effects of surgical incision on the levels of S-NR2B, CDK5, P35, P25, and TNF- $\alpha$ in mice cortex. The surgical incision does not reduce the S-NR2B levels $(\boldsymbol{A})$, does not increase the levels of CDK5 (B), P35 and P25 ( $\boldsymbol{C}$, and TNF- $\alpha(\boldsymbol{D})$ as compared with

Figure 9. Effects of surgical incision on the levels of S-NR2B, CDK5, P35, P25, and TNF- $\alpha$ in mice hippocampus. The surgical B incision does not reduce the S-NR2B levels $(\boldsymbol{A})$, does not increase the levels of CDK5 $(\boldsymbol{B})$, P35 and P25 (C), and TNF- $\alpha(\boldsymbol{D})$ as compared with the sham condition in mice hippocampus at $3 \mathrm{~d}$ post incision.

levels might be dependent on the surgical incision-induced elevation of CDK5.

The surgical incision-induced nociception increased TNF- $\alpha$ levels in mice cortex

TNF- $\alpha$ has been shown to regulate CDK5 activity, contributing to inflammation-induced pain signaling (Utreras et al., 2009). We therefore determined the effects of the surgical incision on brain TNF- $\alpha$ levels in the mice. We found that the surgical incision increased the levels of TNF- $\alpha$ in the cortex (Fig. 7A). The EMLA treatment attenuated the surgical incision-induced elevation in TNF- $\alpha$ levels in the cortex (Fig. 7A). Quantification of the Western blot, based on the ratio of TNF- $\alpha$ to $\beta$-actin, showed that the surgical incision was able to increase the TNF- $\alpha$ levels in the cortex of mice, which was mitigated by the EMLA treatment (Fig. $7 B ; F=7.47, p=0.026, \mathrm{df}=1$, two-way ANOVA). The EMLA-treated incision mice had lesser levels of TNF- $\alpha$ (Fig. 7B) as compared with the control-treated incision mice $\left({ }^{*} p=0.030\right.$, post hoc Bonferroni test).

The surgical incision-induced nociception did not lead to the biochemistry and behavioral changes at different times post incision, in different brain regions, or with different ages of the mice

The surgical incision did not significantly alter the levels of S-NR2B, CDK5, P35, and P25 in the cortex of mice at $7 \mathrm{~d}$ post incision (Fig. 8) nor in the hippocampus of mice at $3 \mathrm{~d}$ post incision (Fig. 9).

Finally, we asked whether the surgical incision might also induce learning impairment in the younger mice. We used 
A
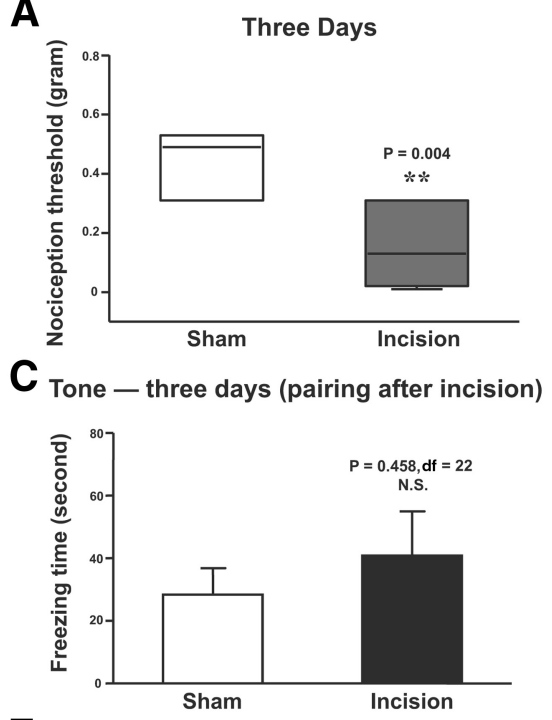

E

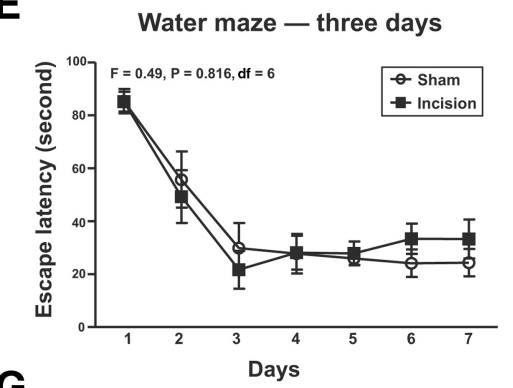

B

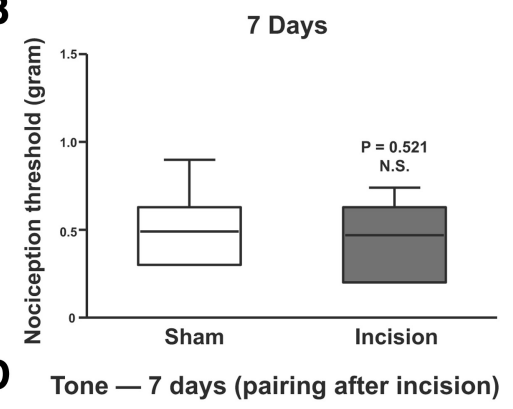

$\mathbf{F}$
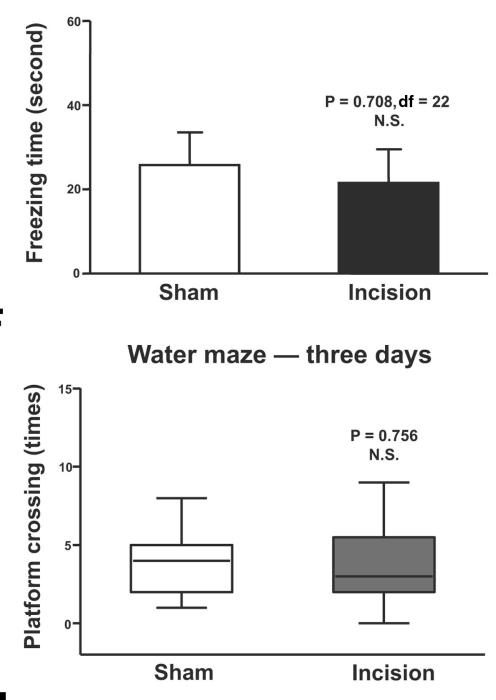

H

3-month old mice in the experiments and found that the surgical incision in the hindpaw of mice reduced nociception threshold as compared with the sham condition at $3 \mathrm{~d}$ (Fig. 10A), but not $7 \mathrm{~d}$ (Fig. 10B), post incision. However, the surgical incision did not significantly reduce the freezing time in the tone test of FCS at $3 \mathrm{~d}$ or $7 \mathrm{~d}$ after the incision (Fig. $10 C, D)$. The surgical incision did not reduce escape latency (Fig. 10E) and did not increase the platform crossing times (Fig. $10 F$ ) of the MWM test. The surgical incision increased the levels of TNF- $\alpha$, but not CDK5, F35, F25, and S-NR2B, and the surgical incision did not reduce the levels of S-NR2B and Es-NR2B in the mice cortex (Fig. 10G-L).

Collectively, these data implied that the surgical incision-induced nociception in the 9-month-old, but not 3-month-old mice might enhance TNF- $\alpha$ levels in the cortex of mice, which increased CDK5 levels, leading to a reduction in S-NR2B levels in the medial prefrontal cortex of mice, and ultimately a hippocampusindependent learning impairment in the mice (Fig. 11).

\section{Discussion}

We demonstrated that the surgical incisioninduced nociception caused learning impairment in mice at 3 and $7 \mathrm{~d}$, but not $30 \mathrm{~d}$, post incision. Moreover, the surgical incision only caused learning impairment in the tone test of FCS, which assesses hippocampus-independent learning and memory function (Kim and Fanselow, 1992; Anagnostaras et al., 1999; Kitamura et al., 2009; Wiltgen et al., 2010; Zhu et al., 2012), but not in the context test of FCS, which assesses hippocampus-dependent learning and memory function (Kim and Fanselow, 1992; Anagnostaras et al., 1999; Kitamura et al., 2009; Wiltgen et al., 2010; Zhu et al., 2012; Fig. 2). These findings suggested that the surgical incision could selectively cause hippocampus-independent learning impairment. Furthermore, the surgical incision only caused learning impairment when the pairing of FCS occurred after the incision but not before the incision (Fig. 2). These data suggested that the surgical incision might only impair mice from learning new tasks, but not from retaining old tasks. The surgical incision did not significantly alter escape latency or platform crossing times in the MWM (which also assess the hippocampus-dependent learning impairment; Fig. $2 K, L)$. These data suggested that the surgical incision might not induce spatial learning and memory impairment in the mice. 


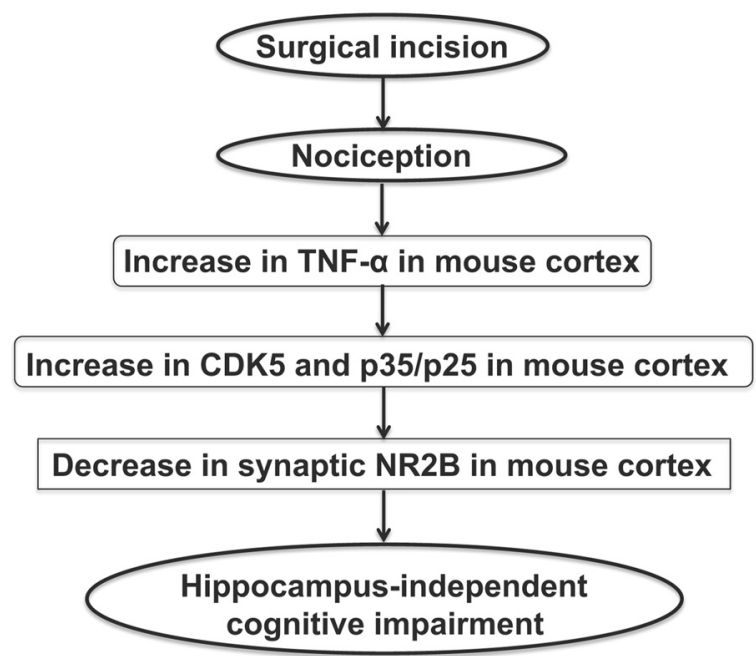

Figure 11. Hypothesized pathway of surgical incision-induced learning impairment. Surgical incision causes nociception in the mice, which may increase the levels of TNF- $\alpha$ in the mouse cortex, leading to elevation of CDK5 levels in the mouse cortex. The elevated CDK5 levels then reduce synaptic NR2B levels in the mouse cortex, ultimately leading to hippocampusindependent learning impairment.

EMLA treatment mitigated the surgical incision-induced nociception (Fig. $3 A, B$ ), and learning impairment (Fig. $3 C, D$ ) in the mice. These findings suggested that the surgical incision could have induced nociception, which then caused learning impairment in the mice. However, it is still possible that the surgical incision induced inflammation, which caused the learning impairment given the anti-inflammatory effect of local anesthetics. The surgical incision reduced the levels of S-NR2B (but neither total NR2B nor Es-NR2B) specifically in the medial prefrontal cortex (Fig. 4), but not in the lateral prefrontal cortex, cingulate cortex, amygdala (data not shown), and hippocampus (Fig. 9) of the mice. Amygdala and medial prefrontal cortex are two brain regions that play an important role in the fear conditioning learning and memory (Tan et al., 2010; Marek et al., 2013). Hippocampus also contributes to the fear conditioning learning and memory (Koseki et al., 2009). The findings that the surgical incision-induced nociception caused hippocampus-independent learning impairment and reduced S-NR2B levels in medial prefrontal cortex (but not other brain regions, e.g., amygdala and hippocampus) suggested that reduction in S-NR2B levels specifically in the medial prefrontal cortex could be, at least partially, the underlying mechanisms by which surgical incision-induced nociception caused learning impairment.

A recent study has reported that neuropathic pain may alter medial prefrontal cortex populational firing activity patterns, leading to impairment of spatial memory (Cardoso-Cruz et al., 2013). Consistently, the current study showed that the NR2B in the medial prefrontal cortex may be responsible for the associative cognitive impairment caused by surgical incision-induced nociception. However, the studies by Cardoso-Cruz et al. (2013)) assessed the spatial memory and neural activity signals, whereas the current study focused on spatial and associative memory, as well as NR2B levels in the medial prefrontal cortex.

NR2B in hippocampus and/or cortex has been reported to contribute to fear conditioning learning and memory (Tang et al., 1999; Rodrigues et al., 2001; Zhao et al., 2005; Dalton et al., 2008; Zhang et al., 2008b) but not spatial memory in rodents tested in MWM (Guscott et al., 2003; for review, see Qiu et al., 2011). NR2B in hippocampus and/or cortex is also involved in chronic pain (Wei et al., 2001, 2002; Liauw et al., 2005; Wu et al., 2005; for review, see Qiu et al., 2011). TNF- $\alpha$ has been shown to contribute to pain (Narita et al., 2008; Gao and Ji, 2010) and learning and memory function (Terrando et al., 2010; Shen et al., 2013). Consistently, our current data suggested that the surgical incision increased TNF- $\alpha$ levels and decreased NR2B levels in mouse brain tissues, and caused fear conditioning learning impairment in the mice. Moreover, the surgical incision only reduced the levels of S-NR2B, but not the Es-NR2B, in the cortex (Fig. 4). S-NR2B is involved in nociception (Wei et al., 2001), learning, and memory (Rodrigues et al., 2001; Zhuo, 2009), whereas Es-NR2B is involved in cell damage (Hardingham et al., 2002; for review, see Hardingham and Bading, 2010). We therefore postulate that S-NR2B is specifically responsible for the learning impairment associated with the surgical incisioninduced nociception.

Interestingly, the surgical incision-induced nociception caused learning impairment at both 3 and $7 \mathrm{~d}$ post incision. However, the surgical incision-induced nociception only decreased the S-NR2B levels in the cortex at $3 \mathrm{~d}$ (Fig. 4), but not $7 \mathrm{~d}$ (Fig. 8), post incision. The underlying mechanisms of the observations remain unknown. It is possible that the surgical incision-induced nociception reduced the S-NR2B levels at $3 \mathrm{~d}$ post incision, which then caused other changes associated with learning and memory, e.g., synaptic dysfunction, at $7 \mathrm{~d}$ post incision, leading to the observed fearing learning impairment.

Furthermore, the surgical incision-induced nociception increased the levels of CDK5 and its activators P35 and P25 (Patrick et al., 1999; Kusakawa et al., 2000; Lee et al., 2000; Cruz et al., 2003; Asada et al., 2008) in the cortex (Fig. 5). CDK5 has been shown to regulate NR2B levels (Sato et al., 2008; Zhang et al., 2008a), and CDK5 inhibitor roscovitine attenuated the surgical incision-induced hippocampus-independent learning impairment and reduction in S-NR2B levels in the cortex (Fig. 6). Finally, the surgical incision-induced nociception increased the levels of TNF- $\alpha$ in the cortex (Fig. 7). TNF- $\alpha$ regulates CDK5 activity and contributes to inflammation-induced pain signaling (Utreras et al., 2009). Collectively, these data suggest that the surgical incision-induced nociception may increase TNF- $\alpha$ levels in the cortex of mice, which increases CDK5 levels, leading to reduction of S-NR2B levels in the medial prefrontal cortex, and ultimately hippocampus-independent learning impairment (Fig. 11). However, it is still possible that the fear conditioning learning impairment following the surgical incision is not associated with these changes because EMLA or roscovitine treatment could not provide direct causal relationship between S-NR2B and fear conditioning learning impairment. Nevertheless, NR2B has been reported to contribute to both cognition and nociception (for review, see Qiu et al., 2011), and other studies have illustrated that brain ischemia may also induce cognitive impairment through alterations in brain NR2B levels (Okiyama et al., 1997; Huang et al., 2008).

The surgical incision-induced nociception did not significantly alter the levels of S-NR2B, Es-NR2B, CDK5, P35, and P25 in brain, and did not cause learning and memory impairment (Fig. 10) in 3-month-old mice. The surgical incision-induced nociception only increased the TNF- $\alpha$ levels in the cortex of the younger mice. The reason why the surgical incision-induced nociception only caused fear conditioning learning impairment in 9-month-old, but not 3-month-old mice is unknown at this time. It is hypothesized that the other changes in brain, e.g., agingassociated accumulation of $\beta$-amyloid in brain (Fukumoto et al., 2004), may facilitate the neurotoxic effects of surgical incision- 
induced nociception, leading to neurobehavioral deficits. The current findings have established a system to embark on future studies to test this hypothesis.

Sleep disturbance in mice may cause hippocampusdependent learning and memory impairment (Zhu et al., 2012). In the current studies, however, the surgical incision-induced nociception might cause hippocampus-independent learning impairment (Fig. 2). Therefore, it is unlikely that the sleep disturbance, which might be associated with the surgical incision-induced nociception, may contribute to the surgical incision-induced hippocampusindependent learning impairment, although such a possibility cannot be totally excluded.

The studies have several limitations. First, we only assessed the effects of the surgical incision-induced nociception on the brain levels of NR2B and cognitive function. It is likely that nociception induced by different insults (e.g., thermal properties and chemistry stimulation) may lead to different profiles of neurobiochemistry and neurobehavioral changes. Nevertheless, the current findings have established and characterized a preclinical system of surgical incision-induced nociception and learning impairment, and furthermore have shown that the surgical incisioninduced nociception may lead to hippocampus-independent learning impairment and reduction in NR2B levels in medial prefrontal cortex. Second, we did not assess the effects of the surgical incision-induced nociception on other domains of cognitive function, e.g., executive function. However, the findings that the nociception can impair learning function, the primary domain of cognitive function, suggest that the surgical incisioninduced nociception could contribute to POCD, pending further studies.

In conclusion, we found that the surgical incision-induced nociception increased the levels of TNF- $\alpha$, CDK5, P35, and P25 in cortex, and reduced the S-NR2B levels in the medial prefrontal cortex, but not hippocampus. The surgical incision-induced nociception impaired hippocampus-independent learning in the mice. Finally, a CDK5 inhibitor attenuated the learning impairment and reduction in S-NR2B levels in the mice. These results suggest that surgical incision-induced nociception might cause learning impairment via reduction in S-NR2B levels, pending further studies. These findings would promote more studies to further determine the role of pain in cognitive function decline, leading to elucidation of the underlying mechanisms of POCD, which could ultimately improve the outcomes of surgical care in patients.

\section{References}

Abe T, Matsumura S, Katano T, Mabuchi T, Takagi K, Xu L, Yamamoto A, Hattori K, Yagi T, Watanabe M, Nakazawa T, Yamamoto T, Mishina M, Nakai Y, Ito S (2005) Fyn kinase-mediated phosphorylation of NMDA receptor NR2B subunit at Tyr1472 is essential for maintenance of neuropathic pain. Eur J Neurosci 22:1445-1454. CrossRef Medline

Anagnostaras SG, Maren S, Fanselow MS (1999) Temporally graded retrograde amnesia of contextual fear after hippocampal damage in rats: within-subjects examination. J Neurosci 19:1106-1114. Medline

Apfelbaum JL, Chen C, Mehta SS, Gan TJ (2003) Postoperative pain experience: results from a national survey suggest postoperative pain continues to be undermanaged. Anesth Analg 97:534-540, table of contents. CrossRef Medline

Asada A, Yamamoto N, Gohda M, Saito T, Hayashi N, Hisanaga S (2008) Myristoylation of p39 and p35 is a determinant of cytoplasmic or nuclear localization of active cyclin-dependent kinase 5 complexes. J Neurochem 106:1325-1336. CrossRef Medline

Bauer EP, Schafe GE, LeDoux JE (2002) NMDA receptors and L-type voltage-gated calcium channels contribute to long-term potentiation and different components of fear memory formation in the lateral amygdala. J Neurosci 22:5239-5249. Medline
Berberich S, Jensen V, Hvalby Ø, Seeburg PH, Köhr G (2007) The role of NMDAR subtypes and charge transfer during hippocampal LTP induction. Neuropharmacology 52:77-86. CrossRef Medline

Bianchi SL, Tran T, Liu C, Lin S, Li Y, Keller JM, Eckenhoff RG, Eckenhoff MF (2008) Brain and behavior changes in 12-month-old Tg2576 and nontransgenic mice exposed to anesthetics. Neurobiol Aging 29:1002-1010. CrossRef Medline

Cardoso-Cruz H, Lima D, Galhardo V (2013) Impaired spatial memory performance in a rat model of neuropathic pain is associated with reduced hippocampus-prefrontal cortex connectivity. J Neurosci 33:2465-2480. CrossRef Medline

Chaplan SR, Bach FW, Pogrel JW, Chung JM, Yaksh TL (1994) Quantitative assessment of tactile allodynia in the rat paw. J Neurosci Methods 53:5563. CrossRef Medline

Cibelli M, Fidalgo AR, Terrando N, Ma D, Monaco C, Feldmann M, Takata M, Lever IJ, Nanchahal J, Fanselow MS, Maze M (2010) Role of interleukin-1beta in postoperative cognitive dysfunction. Ann Neurol 68: 360-368. CrossRef Medline

Cotman CW, Taylor D (1972) Isolation and structural studies on synaptic complexes from rat brain. J Cell Biol 55:696-711. CrossRef Medline

Cruz JC, Tseng HC, Goldman JA, Shih H, Tsai LH (2003) Aberrant Cdk5 activation by $\mathrm{p} 25$ triggers pathological events leading to neurodegeneration and neurofibrillary tangles. Neuron 40:471-483. CrossRef Medline

Dalton GL, Wang YT, Floresco SB, Phillips AG (2008) Disruption of AMPA receptor endocytosis impairs the extinction, but not acquisition of learned fear. Neuropsychopharmacology 33:2416-2426. CrossRef Medline

Deiner S, Silverstein JH (2009) Postoperative delirium and cognitive dysfunction. Br J Anaesth 103 [Suppl 1]:i41-i46. CrossRef Medline.

Fukumoto H, Rosene DL, Moss MB, Raju S, Hyman BT, Irizarry MC (2004) Beta-secretase activity increases with aging in human, monkey, and mouse brain. Am J Pathol 164:719-725. CrossRef Medline

Gao YJ, Ji RR (2010) Chemokines, neuronal-glial interactions, and central processing of neuropathic pain. Pharmacol Ther 126:56-68. CrossRef Medline

Goebel-Goody SM, Davies KD, Alvestad Linger RM, Freund RK, Browning MD (2009) Phospho-regulation of synaptic and extrasynaptic $\mathrm{N}$-methyl-d-aspartate receptors in adult hippocampal slices. Neuroscience 158:1446-1459. CrossRef Medline

Guscott MR, Clarke HF, Murray F, Grimwood S, Bristow LJ, Hutson PH (2003) The effect of (+/-)-CP-101,606, an NMDA receptor NR2B subunit selective antagonist, in the Morris water maze. Eur J Pharmacol 476:193-199. CrossRef Medline

Hardingham GE, Bading H (2010) Synaptic versus extrasynaptic NMDA receptor signalling: implications for neurodegenerative disorders. Nat Rev Neurosci 11:682-696. CrossRef Medline

Hardingham GE, Fukunaga Y, Bading H (2002) Extrasynaptic NMDARs oppose synaptic NMDARs by triggering CREB shut-off and cell death pathways. Nat Neurosci 5:405-414. Medline

Huang L, He Z, Guo L, Wang H (2008) Improvement of cognitive deficit and neuronal damage in rats with chronic cerebral ischemia via relative long-term inhibition of rho-kinase. Cell Mol Neurobiol 28:757-768. CrossRef Medline

Johansen JP, Cain CK, Ostroff LE, LeDoux JE (2011) Molecular mechanisms of fear learning and memory. Cell 147:509-524. CrossRef Medline

Kim JJ, Fanselow MS (1992) Modality-specific retrograde amnesia of fear. Science 256:675-677. CrossRef Medline

Kitamura T, Saitoh Y, Takashima N, Murayama A, Niibori Y, Ageta H, Sekiguchi M, Sugiyama H, Inokuchi K (2009) Adult neurogenesis modulates the hippocampus-dependent period of associative fear memory. Cell 139:814-827. CrossRef Medline

Koseki H, Matsumoto M, Togashi H, Miura Y, Fukushima K, Yoshioka M (2009) Alteration of synaptic transmission in the hippocampal-mPFC pathway during extinction trials of context-dependent fear memory in juvenile rat stress models. Synapse 63:805-813. CrossRef Medline

Kusakawa G, Saito T, Onuki R, Ishiguro K, Kishimoto T, Hisanaga S (2000) Calpain-dependent proteolytic cleavage of the $\mathrm{p} 35$ cyclin-dependent kinase 5 activator to p25. J Biol Chem 275:17166-17172. CrossRef Medline

Lee MS, Kwon YT, Li M, Peng J, Friedlander RM, Tsai LH (2000) Neurotoxicity induces cleavage of p35 to p25 by calpain. Nature 405:360-364. CrossRef Medline

Li S, Jin M, Koeglsperger T, Shepardson NE, Shankar GM, Selkoe DJ (2011) Soluble Abeta oligomers inhibit long-term potentiation through a mech- 
anism involving excessive activation of extrasynaptic NR2B-containing NMDA receptors. J Neurosci 31:6627-6638. CrossRef Medline

Liauw J, Wu LJ, Zhuo M (2005) Calcium-stimulated adenylyl cyclases required for long-term potentiation in the anterior cingulate cortex. J Neurophysiol 94:878-882. CrossRef Medline

Liu L, Wong TP, Pozza MF, Lingenhoehl K, Wang Y, Sheng M, Auberson YP, Wang YT (2004) Role of NMDA receptor subtypes in governing the direction of hippocampal synaptic plasticity. Science 304:1021-1024. CrossRef Medline

Marek R, Strobel C, Bredy TW, Sah P (2013) The amygdala and medial prefrontal cortex: partners in the fear circuit. J Physiol 591:2381-2391. Medline

Maren S, Phan KL, Liberzon I (2013) The contextual brain: implications for fear conditioning, extinction and psychopathology. Nat Rev Neurosci 14:417-428. CrossRef Medline

Miwa H, Fukaya M, Watabe AM, Watanabe M, Manabe T (2008) Functional contributions of synaptically localized NR2B subunits of the NMDA receptor to synaptic transmission and long-term potentiation in the adult mouse CNS. J Physiol 586:2539-2550. CrossRef Medline

Moller JT, Cluitmans P, Rasmussen LS, Houx P, Rasmussen H, Canet J, Rabbitt P, Jolles J, Larsen K, Hanning CD, Langeron O, Johnson T, Lauven PM, Kristensen PA, Biedler A, van Beem H, Fraidakis O, Silverstein JH, Beneken JE, Gravenstein JS (1998) Long-term postoperative cognitive dysfunction in the elderly ISPOCD1 study. ISPOCD investigators. Lancet 351:857-861. CrossRef Medline

Monk TG, Weldon BC, Garvan CW, Dede DE, van der Aa MT, Heilman KM, Gravenstein JS (2008) Predictors of cognitive dysfunction after major noncardiac surgery. Anesthesiology 108:18-30. CrossRef Medline

Narita M, Shimamura M, Imai S, Kubota C, Yajima Y, Takagi T, Shiokawa M, Inoue T, Suzuki M, Suzuki T (2008) Role of interleukin-1beta and tumor necrosis factor-alpha-dependent expression of cyclooxygenase-2 mRNA in thermal hyperalgesia induced by chronic inflammation in mice. Neuroscience 152:477-486. CrossRef Medline

Okiyama K, Smith DH, White WF, Richter K, McIntosh TK (1997) Effects of the novel NMDA antagonists CP-98,113, CP-101,581 and CP-101,606 on cognitive function and regional cerebral edema following experimental brain injury in the rat. J Neurotrauma 14:211-222. CrossRef Medline

Patrick GN, Zukerberg L, Nikolic M, de la Monte S, Dikkes P, Tsai LH (1999) Conversion of $\mathrm{p} 35$ to $\mathrm{p} 25$ deregulates $\mathrm{Cdk} 5$ activity and promotes neurodegeneration. Nature 402:615-622. CrossRef Medline

Phillips-Bute B, Mathew JP, Blumenthal JA, Grocott HP, Laskowitz DT, Jones RH, Mark DB, Newman MF (2006) Association of neurocognitive function and quality of life 1 year after coronary artery bypass graft (CABG) surgery. Psychosom Med 68:369-375. CrossRef Medline

Pogatzki EM, Raja SN (2003) A mouse model of incisional pain. Anesthesiology 99:1023-1027. CrossRef Medline

Qiu S, Li XY, Zhuo M (2011) Post-translational modification of NMDA receptor GluN2B subunit and its roles in chronic pain and memory. Semin Cell Dev Biol 22:521-529. CrossRef Medline

Rodrigues SM, Schafe GE, LeDoux JE (2001) Intra-amygdala blockade of the NR2B subunit of the NMDA receptor disrupts the acquisition but not the expression of fear conditioning. J Neurosci 21:6889-6896. Medline

Saab BJ, Maclean AJ, Kanisek M, Zurek AA, Martin LJ, Roder JC, Orser BA (2010) Short-term memory impairment after isoflurane in mice is prevented by the alpha5 gamma-aminobutyric acid type A receptor inverse agonist L-655,708. Anesthesiology 113:1061-1071. CrossRef Medline

Sato S, Xu J, Okuyama S, Martinez LB, Walsh SM, Jacobsen MT, Swan RJ, Schlautman JD, Ciborowski P, Ikezu T (2008) Spatial learning impairment, enhanced CDK5/p35 activity, and downregulation of NMDA receptor expression in transgenic mice expressing tau-tubulin kinase 1. J Neurosci 28:14511-14521. CrossRef Medline

Satomoto M, Satoh Y, Terui K, Miyao H, Takishima K, Ito M, Imaki J (2009) Neonatal exposure to sevoflurane induces abnormal social behaviors and deficits in fear conditioning in mice. Anesthesiology 110:628-637. CrossRef Medline

Shen X, Dong Y, Xu Z, Wang H, Miao C, Soriano SG, Sun D, Baxter MG, Zhang Y, Xie Z (2013) Selective anesthesia-induced neuroinflammation in developing mouse brain and cognitive impairment. Anesthesiology 118:502-515. CrossRef Medline

Tan H, Lauzon NM, Bishop SF, Bechard MA, Laviolette SR (2010) Integrated cannabinoid $\mathrm{CB} 1$ receptor transmission within the amygdala- prefrontal cortical pathway modulates neuronal plasticity and emotional memory encoding. Cereb Cortex 20:1486-1496. CrossRef Medline

Tang YP, Shimizu E, Dube GR, Rampon C, Kerchner GA, Zhuo M, Liu G, Tsien JZ (1999) Genetic enhancement of learning and memory in mice. Nature 401:63-69. CrossRef Medline

Terrando N, Monaco C, Ma D, Foxwell BM, Feldmann M, Maze M (2010) Tumor necrosis factor-alpha triggers a cytokine cascade yielding postoperative cognitive decline. Proc Natl Acad Sci U S A 107:20518-20522. CrossRef Medline

Terrando N, Brzezinski M, Degos V, Eriksson LI, Kramer JH, Leung JM, Miller BL, Seeley WW, Vacas S, Weiner MW, Yaffe K, Young WL, Xie Z, Maze M (2011) Perioperative cognitive decline in the aging population. Mayo Clin Proc 86:885-893. CrossRef Medline

Utreras E, Futatsugi A, Rudrabhatla P, Keller J, Iadarola MJ, Pant HC, Kulkarni AB (2009) Tumor necrosis factor-alpha regulates cyclindependent kinase 5 activity during pain signaling through transcriptional activation of p35. J Biol Chem 284:2275-2284. Medline

Wan Y, Xu J, Meng F, Bao Y, Ge Y, Lobo N, Vizcaychipi MP, Zhang D, Gentleman SM, Maze M, Ma D (2010) Cognitive decline following major surgery is associated with gliosis, beta-amyloid accumulation, and tau phosphorylation in old mice. Crit Care Med.

Wang Y, Sands LP, Vaurio L, Mullen EA, Leung JM (2007) The effects of postoperative pain and its management on postoperative cognitive dysfunction. Am J Geriatr Psychiatry 15:50-59. CrossRef Medline

Weaver IC, Meaney MJ, Szyf M (2006) Maternal care effects on the hippocampal transcriptome and anxiety-mediated behaviors in the offspring that are reversible in adulthood. Proc Natl Acad Sci U S A 103:3480-3485. CrossRef Medline

Wei F, Wang GD, Kerchner GA, Kim SJ, Xu HM, Chen ZF, Zhuo M (2001) Genetic enhancement of inflammatory pain by forebrain NR2B overexpression. Nat Neurosci 4:164-169. CrossRef Medline

Wei F, Qiu CS, Kim SJ, Muglia L, Maas JW, Pineda VV, Xu HM, Chen ZF, Storm DR, Muglia LJ, Zhuo M (2002) Genetic elimination of behavioral sensitization in mice lacking calmodulin-stimulated adenylyl cyclases. Neuron 36:713-726. CrossRef Medline

Wiltgen BJ, Zhou M, Cai Y, Balaji J, Karlsson MG, Parivash SN, Li W, Silva AJ (2010) The hippocampus plays a selective role in the retrieval of detailed contextual memories. Curr Biol 20:1336-1344. CrossRef Medline

Wu LJ, Toyoda H, Zhao MG, Lee YS, Tang J, Ko SW, Jia YH, Shum FW, Zerbinatti CV, Bu G, Wei F, Xu TL, Muglia LJ, Chen ZF, Auberson YP, Kaang BK, Zhuo M (2005) Upregulation of forebrain NMDA NR2B receptors contributes to behavioral sensitization after inflammation. J Neurosci 25:11107-11116. CrossRef Medline

Xie Z, Culley DJ, Dong Y, Zhang G, Zhang B, Moir RD, Frosch MP, Crosby G, Tanzi RE (2008) The common inhalation anesthetic isoflurane induces caspase activation and increases amyloid beta-protein level in vivo. Ann Neurol 64:618-627. CrossRef Medline

Zhang S, Edelmann L, Liu J, Crandall JE, Morabito MA (2008a) Cdk5 regulates the phosphorylation of tyrosine 1472 NR2B and the surface expression of NMDA receptors. J Neurosci 28:415-424. CrossRef Medline

Zhang XH, Liu F, Chen Q, Zhang CL, Zhuo M, Xiong ZQ, Li BM (2008b) Conditioning-strength dependent involvement of NMDA NR2B subtype receptor in the basolateral nucleus of amygdala in acquisition of auditory fear memory. Neuropharmacology 55:238-246. CrossRef Medline

Zhang Y, Xu Z, Wang H, Dong Y, Shi HN, Culley DJ, Crosby G, Marcantonio ER, Tanzi RE, Xie Z (2012) Anesthetics isoflurane and desflurane differently affect mitochondrial function, learning, and memory. Ann Neurol 71:687-698. CrossRef Medline

Zhao MG, Toyoda H, Lee YS, Wu LJ, Ko SW, Zhang XH, Jia Y, Shum F, Xu H, Li BM, Kaang BK, Zhuo M (2005) Roles of NMDA NR2B subtype receptor in prefrontal long-term potentiation and contextual fear memory. Neuron 47:859-872. CrossRef Medline

Zhou Q, Sheng M (2013) NMDA receptors in nervous system diseases. Neuropharmacology 74:69-75. CrossRef Medline

Zhu B, Dong Y, Xu Z, Gompf HS, Ward SA, Xue Z, Miao C, Zhang Y, Chamberlin NL, Xie Z (2012) Sleep disturbance induces neuroinflammation and impairment of learning and memory. Neurobiol Dis 48:348355. CrossRef Medline

Zhuo M (2009) Plasticity of NMDA receptor NR2B subunit in memory and chronic pain. Mol Brain 2:4. CrossRef Medline 